\title{
Use of sugarcane molasses by Pycnoporus sanguineus for the production of laccase for dye decolorization
}

\author{
R.A. Marim, A.C.C. Oliveira, R.S. Marquezoni, J.P.R. Servantes, \\ B.K. Cardoso, G.A. Linde, N.B. Colauto and J.S. Valle \\ Programa de Pós-Graduação em Biotecnologia Aplicada à Agricultura, \\ Universidade Paranaense, Umuarama, PR, Brasil \\ Corresponding author: J.S. Valle \\ E-mail: jsvalle@unipar.br
}

Genet. Mol. Res. 15 (4): gmr15048972

Received July 14, 2016

Accepted August 15, 2016

Published October 17, 2016

DOI http://dx.doi.org/10.4238/gmr15048972

Copyright (C) 2016 The Authors. This is an open-access article distributed under the terms of the Creative Commons Attribution ShareAlike (CC BY-SA) 4.0 License.

ABSTRACT. Pycnoporus sanguineus is a white-rot basidiomycete that
produces laccase as the only oxidoreductase; enzyme synthesis depends
on cultivation variables, and fungal species and strain. Laccases have
wide substrate specificity, oxidize a broad range of compounds, and
show potential for use in dye decolorization. We evaluated laccase
production in a recently isolated strain of $P$. sanguineus cultivated with
sugarcane molasses as the only carbon source, and urea or yeast extract
as the nitrogen source [at various nitrogen concentrations $(0.4,1.4,2.4$,
3.4$, and $4.4 \mathrm{~g} / \mathrm{L})$ ], supplemented with copper $(0,150,200,250$, and
$300 \mu \mathrm{M})$, with or without agitation. The enzymatic extract produced
at laccase peak activity was tested for dye decolorization capability
on Remazol Brilliant Blue R, Reactive Black 5 , Reactive Red 195 ,
and Reactive Yellow 145 . The nitrogen source did not affect enzyme
production and the higher nitrogen concentration $(3.4 \mathrm{~g} / \mathrm{L}$ nitrogen as

Genetics and Molecular Research 15 (4): gmr15048972 
urea) increased enzymatic activity. The addition of up to $300 \mu \mathrm{M}$ of $\mathrm{Cu}$ did not affect laccase production, whereas cultivation with agitation increased the activity peak by $17 \%$. The highest laccase activity was $\sim 50,000 \mathrm{U} / \mathrm{L}$ on the ninth day of cultivation. After $24 \mathrm{~h}$, decolorization was $80 \%$ for Remazol Brilliant Blue R, 9\% for Reactive Yellow 145, $6 \%$ for Reactive Red 195, and 2\% for Reactive Black 5. The enzymatic extract of $P$. sanguineus provides a potential alternative to wastewater treatment. A better understanding of the behavior of this fungus under various culture conditions would allow improvement of the enzyme production bioprocess.

Key words: Basidiomycete; Agro-industrial waste; Decolorization; Anthraquinone dye; Azo dye

\section{INTRODUCTION}

The industrial expansion and broad utilization of dyes, mainly in the textile sector, has resulted in an increase of highly polluting colored effluents. Effluents contain complex mixtures of dyes and salts with high toxicity and biochemical and chemical oxygen demand (Rodriguez-Couto, 2013). Approximately ten thousand types of synthetic dyes are used in the textile, paper, printing, and leather tanning industries, corresponding to $7 \times 10^{5}$ tons of dye per year (Annuar et al., 2009). The main chemical classes of synthetic dyes used in industrial processes are azo, anthraquinone, nitro, nitrous, indigo, triphenylmethane, and phthalein. Most of these compounds have a complex and stable toxic molecular structure that is persistent in the environment. The treatment and decolorization of dye effluents is difficult, and a great variety of physical and chemical techniques have been developed to remove them, including adsorption by organic or inorganic matrices, decolorization by photocatalysis, irradiation, and filtration (Joo et al., 2007). The physical and chemical methods used are usually associated with biological treatment through an activated sludge system. However, this approach is not always efficient for the removal of dyes; it generates large amounts of sludge and requires high-cost additional treatments such as oxidative processes (Rodriguez-Couto, 2013).

The oxidoreductive enzymes produced by white-rot fungi (WRF) are capable of degrading a variety of textile dyes, and enzyme-mediated decolorization is a promising alternative to conventional treatments. Enzymes from WRF can detoxify effluents and sludge and enable their re-introduction into the environment. Laccases (EC 1.10.3.2) are ligninases that are also known as copper polyphenol oxidases; they utilize the redox potential of copper ions to catalyze the oxidation of phenolic substrates, while reducing molecular oxygen to water. These enzymes are capable of oxidizing a broad variety of natural substrates such as phenols and polyphenols, making them attractive for applications in the textile, food, paper, pharmaceutical, chemical, and bioremediation industries (Piscitelli et al., 2011). Although fungal enzymes can promote the degradation of dyes, no single enzymatic model is capable of acting on all dye classes. Therefore, there is a constant demand for new enzymes from different sources and with distinct characteristics that are capable of providing the variety required by industry.

We identified a recently isolated strain of Pycnoporus sanguineus (Basidiomycota) as a laccase producer. This species is found in tropical and subtropical areas and is known for

Genetics and Molecular Research 15 (4): gmr15048972 
its high lignocellulolytic potential, for producing laccase as its main extracellular ligninase (Hernández et al., 2016), and for effectively degrading several classes of dyes (Moreira-Neto et al., 2013). However, laccase production depends on fungal cultivation and growth conditions, and the expression of different laccase isozymes is related to the presence of nutrients and inducers in the cultivation media (Valle et al., 2015). Different laccase isoforms may have distinct roles in fungal physiology and could be used for applications other than those already known.

P. sanguineus and other WRF can be grown using by-products derived from the agroindustry. In the present study, we report for the first time the use of sugarcane molasses as a low-cost carbon source in the production of $P$. sanguineus laccase. In Brazil, 663 million tons of sugarcane were produced in the 2015-2016 crop, generating 27-40 million tons of molasses (CONAB - Companhia Nacional de Abastecimento, 2015). Sugarcane molasses is a by-product of the final crystallization in the sugar production process. It is rich in fermentable sugars as well as amino acids, vitamins, proteins, and minerals. Owing to its composition and large-scale production, sugarcane molasses can be used as a supplement in animal feed and in ethanol production, and it is a potential substrate for biotechnological processes such as enzyme production (Valle et al., 2014a). The aim of this study was to cultivate P. sanguineus in sugarcane molasses with two different nitrogen sources and various concentrations of copper and nitrogen, with and without agitation, to evaluate laccase production and its dye decolorization capability.

\section{MATERIAL AND METHODS}

\section{Microorganism}

P. sanguineus (L.) Murrill (Polyporaceae) strain U13-4 from the Laboratory of Molecular Biology of Universidade Paranaense was grown on malt extract agar (MEA) medium $(20 \mathrm{~g} / \mathrm{L})$ at $28^{\circ} \mathrm{C}$ for 7 days, and was used as an inoculum for laccase production.

\section{Cultivation medium with two nitrogen sources}

The cultivation medium comprised sugarcane molasses, $\mathrm{KH}_{2} \mathrm{PO}_{4}(1 \mathrm{~g} / \mathrm{L}), \mathrm{MgSO}_{4} \cdot 7 \mathrm{H}_{2} \mathrm{O}$ $(0.5 \mathrm{~g} / \mathrm{L})$, and $\mathrm{FeSO}_{4} \cdot 7 \mathrm{H}_{2} \mathrm{O}(0.01 \mathrm{~g} / \mathrm{L})$; yeast extract or urea were added as nitrogen sources until the final nitrogen concentration of $2.4 \mathrm{~g} / \mathrm{L}$ was reached in the cultivation medium. Molasses were added in sufficient quantity to obtain a final concentration of $10 \mathrm{~g} / \mathrm{L}$ total sugars. The cultivation medium $(100 \mathrm{~mL})$ was transferred to 250 - $\mathrm{mL}$ flasks and autoclaved at $121^{\circ} \mathrm{C}$ for 20 $\mathrm{min}$, except for the urea solution, which was filtered $(0.22-\mu \mathrm{m}$ porous filter $)$ and added later. After cooling, the cultivation medium was inoculated with three MEA disks of 6-mm diameter containing mycelium, and kept at $28^{\circ} \mathrm{C}$ for 12 days in the dark. The best nitrogen source for laccase production was selected for the subsequent experiments.

\section{Cultivation medium with various nitrogen and copper concentrations}

The final nitrogen concentrations added to the culture medium were $0.4,1.4,2.4,3.4$, and $4.4 \mathrm{~g} / \mathrm{L}$. The best nitrogen concentration for laccase production was selected to evaluate the effect of copper $\left(\mathrm{CuSO}_{4}\right)$ addition. Copper was added to the culture medium at concentrations

Genetics and Molecular Research 15 (4): gmr15048972 
of $0,150,200,250$, and $300 \mu \mathrm{M}$. The best copper concentration for laccase production was selected to evaluate the effect of agitated $(90 \mathrm{rpm})$ or static conditions in the culture medium. Laccase activity was evaluated every $24 \mathrm{~h}$ for 12 days.

All experiments were conducted using three replicates, the results were evaluated by analysis of variance (ANOVA), and differences among averages were determined using the Scott-Knott test $(\mathrm{P} \leq 0.05)$.

\section{Laccase assay}

Laccase activity was evaluated by the oxidation of $1 \mathrm{mM}$ 2,2'-azino-bis(3ethylbenzothiazoline-6-sulfonate) (ABTS). The enzymatic activity was determined in a reaction mixture containing $0.2 \mathrm{~mL}$ cultivation medium, $0.7 \mathrm{~mL}$ ultrapure water, $0.45 \mathrm{~mL}$ sodium acetate buffer ( $0.1 \mathrm{M}, \mathrm{pH}$ 5.0), and $0.15 \mathrm{~mL}$ ABTS (Valle et al., 2015). The reaction mixture was maintained at $30^{\circ} \mathrm{C}$ for $10 \mathrm{~min}$ and then $100 \mu \mathrm{L}$ trichloroacetic acid solution $(50 \mathrm{~g} / \mathrm{L})$ was added to the enzymatic reaction. ABTS oxidation was followed by an increase in absorbance at $420 \mathrm{~nm}\left(\varepsilon=36,000 \mathrm{M}^{-1} \cdot \mathrm{cm}^{-1}\right)$. The cultivation medium mixture $(0.2 \mathrm{~mL})$, ultrapure water $(0.85 \mathrm{~mL})$, and sodium acetate buffer $(0.45 \mathrm{~mL})$ were used as an enzyme control; a mixture of ultrapure water $(0.9 \mathrm{~mL})$, sodium acetate buffer $(0.45 \mathrm{~mL})$, and ABTS $(0.15 \mathrm{~mL})$ was used as the analytical control. Laccase activity was expressed in international units $(\mathrm{U})$ and was defined as the amount of enzyme required to oxidize $1 \mu \mathrm{mol}$ ABTS per minute.

\section{Dye decolorization}

For the dye decolorization assays, we used the synthetic anthraquinone dye Remazol Brilliant Blue R (RBBR) and the synthetic azo dyes Reactive Black 5 (RB5), Reactive Red 195 (RR195), and Reactive Yellow 145 (RY145). The dye solutions were prepared at $0.1 \%$ in ultrapure water. The enzymatic extract was obtained by centrifugation of the cultivation medium at $8000 \mathrm{~g}$ for $10 \mathrm{~min}$ at $4^{\circ} \mathrm{C}$. For the decolorization reaction, $3.2 \mathrm{~mL}$ extract, $0.4 \mathrm{~mL}$ sodium acetate buffer $(0.1 \mathrm{M}, \mathrm{pH} 5.0)$, and $0.4 \mathrm{~mL}$ dye solution were mixed. The mixture was maintained at $28^{\circ} \mathrm{C}$ for $24 \mathrm{~h}$ and the decolorization percentage was verified at the peak of absorbance for each dye: RBBR (595 nm), RB5 (597 nm), RR195 (540 nm), and RY145 (416 $\mathrm{nm})$. All assays were carried out in duplicate.

\section{RESULTS}

The sugarcane molasses cultivation medium enabled the production of high titers of laccase, reaching a productivity of $122.5 \mathrm{U} \cdot \mathrm{L}^{-1} \cdot \mathrm{h}^{-1}$ in the cultivation medium with urea and $231.5 \mathrm{U} \cdot \mathrm{L}^{-1} \cdot \mathrm{h}^{-1}$ at the enzymatic peak after culture conditions had been optimized (nitrogen concentration and agitation).

Supplementation with the different nitrogen sources (yeast extract or urea) did not affect laccase production $(\mathrm{P} \leq 0.05)$. When yeast extract was provided, the laccase activity was 35,277 U/L; when urea was used, P. sanguineus produced 35,335 U/L. Therefore, urea was selected for the subsequent assays owing to its lower cost, and ease of use and standardization.

The highest nitrogen concentrations $(3.4$ and $4.4 \mathrm{~g} / \mathrm{L})$ in the cultivation medium increased $P$. sanguineus laccase activity $(\mathrm{P} \leq 0.05)$ (Figure 1$)$; the laccase activities were 27

Genetics and Molecular Research 15 (4): gmr15048972 
and $31 \%$ higher, respectively, than with $2.4 \mathrm{~g} / \mathrm{L}$ nitrogen. However, there was no difference (P $\leq 0.05$ ) in the enzymatic activity for nitrogen concentrations of 3.4 and $4.4 \mathrm{~g} / \mathrm{L}$. Thus, $3.4 \mathrm{~g} / \mathrm{L}$ nitrogen (urea) was selected for the subsequent assays. The addition of up to $300 \mu \mathrm{M}$ copper to the cultivation medium did not affect $P$. sanguineus $(\mathrm{P} \leq 0.05)$ laccase activity (Figure 2$)$, and this fungal strain maintained constitutive enzymatic production.

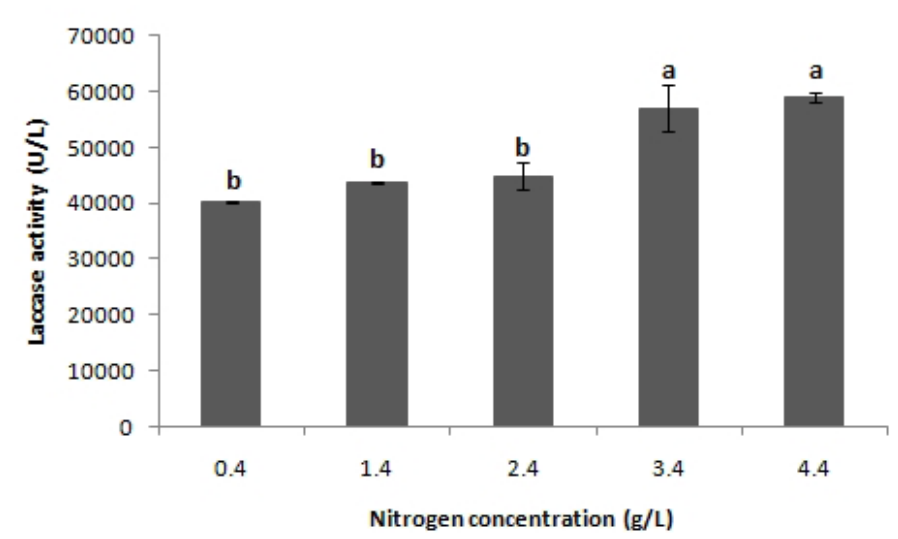

Figure 1. Laccase activity (average \pm standard deviation) of Pycnoporus sanguineus cultivated in sugarcane molasses medium supplemented with various concentrations of nitrogen (urea). Averages indicated by the same letter do not differ statistically according to the Scott-Knott test $(\mathrm{P} \leq 0.05)$.

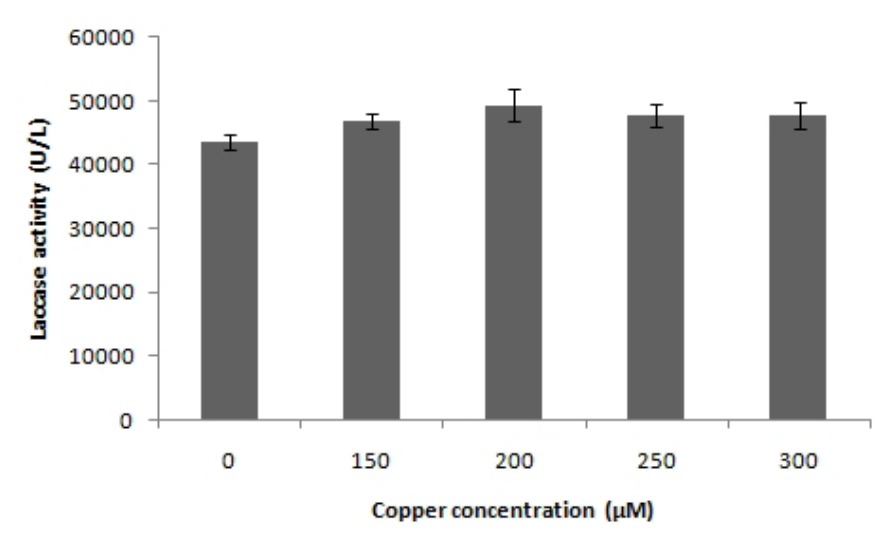

Figure 2. Laccase activity (average \pm standard deviation) of Pycnoporus sanguineus cultivated in sugarcane molasses medium supplemented with urea $(3.4 \mathrm{~g} / \mathrm{L}$ nitrogen $)$ and various concentrations of copper $\left(\mathrm{CuSO}_{4}\right)$. There was no statistical difference among the averages according to the Scott-Knott test $(\mathrm{P} \leq 0.05)$.

P. sanguineus laccase production was monitored every $24 \mathrm{~h}$ for 12 days under the best culture conditions [sugarcane molasses (10 g/L total sugars), urea (3.4 g/L nitrogen), and no copper] under static or agitated cultivation $(90 \mathrm{rpm})$. Agitated cultivation increased $(\mathrm{P} \leq$ 0.05 ) laccase activity and anticipated the beginning of enzymatic production (Figure 3 ). With agitated cultivation, laccase activity was first detected on the third cultivation day, whereas with static cultivation the enzyme was only detected on the fifth day. Peak laccase activity 
occurred on the ninth cultivation day, and was $49,695 \pm 1358 \mathrm{U} / \mathrm{L}\left(230 \mathrm{U} \cdot \mathrm{L}^{-1} \cdot \mathrm{h}^{-1}\right)$ for agitated cultivation and 42,449 $\pm 2094 \mathrm{U} / \mathrm{L}\left(196 \mathrm{U} \cdot \mathrm{L}^{-1} \cdot \mathrm{h}^{-1}\right)$ for static cultivation. Therefore, agitation resulted in a $17 \%$ greater peak (Figure 3 ).

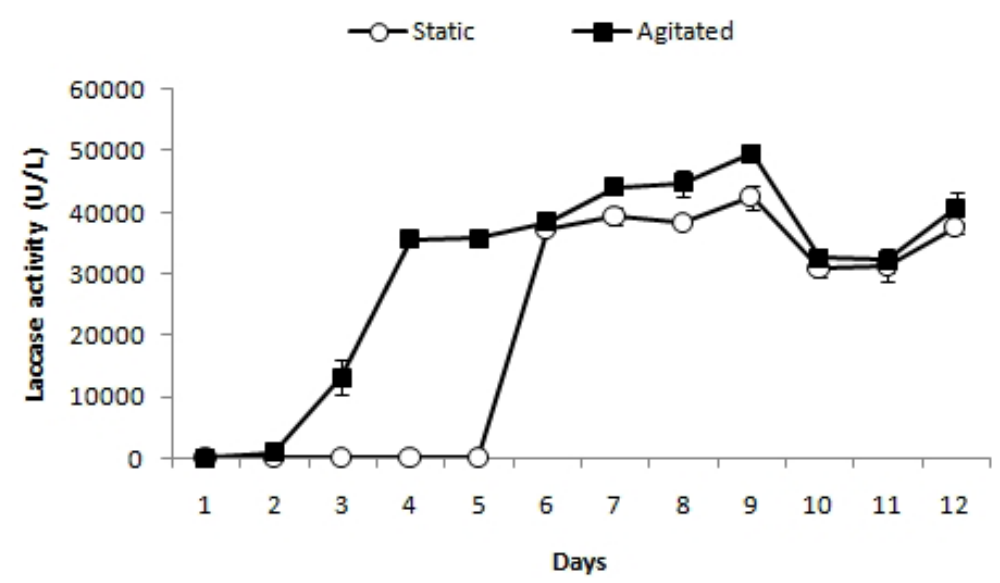

Figure 3. Laccase activity of Pycnoporus sanguineus after 12 days of cultivation in sugarcane molasses medium supplemented with urea $(3.4 \mathrm{~g} / \mathrm{L}$ nitrogen) with or without agitation.

The enzymatic extract obtained from the agitated cultivation at peak laccase activity resulted in partial decolorization of all dyes. Decolorization was observed with absorbance reduction after $24 \mathrm{~h}$. The anthraquinone dye RBBR exhibited the highest decolorization (80\%) (Figure 4). The azo dyes were decolorized to a lesser degree in the same time interval: RY145 (9\%), RR195 (6\%), and RB5 (2\%).

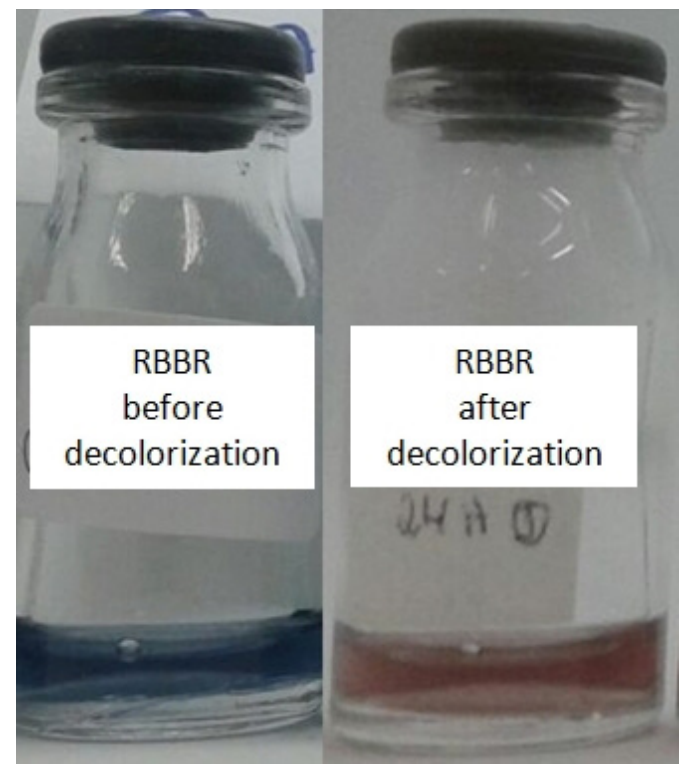

Figure 4. Decolorization of Remazol Brilliant Blue R (RBBR) by the enzymatic extract of Pycnoporus sanguineus. 
Dye decolorization using Pycnoporus sanguineus laccase

\section{DISCUSSION}

P. sanguineus has been successfully cultivated for the production of laccases in a variety of lignocellulosic waste materials or by-products from the agro-industry (Zimbardi et al., 2016). The production of laccase at peak activity and after culture condition optimization using sugarcane molasses was 8.5-fold higher than that reported by Zimbardi et al. (2016) for the RP15 strain of $P$. sanguineus cultivated in wheat bran $(5900 \mathrm{U} / \mathrm{L})$ under solid state fermentation. The production of laccase by P. sanguineus U13-4 was 5-fold higher than laccase production by Agaricus blazei (9700 U/L), also cultivated with sugarcane molasses (Valle et al., 2014a). Sugarcane molasses is rich in sugars (mostly sucrose and glucose), and the easily assimilated substrates present in this by-product seem to favor laccase production.

The effect of nitrogen concentration on laccase production in basidiomycetes is well known and is thought to have an important influence on the production of laccase (Giardina et al., 2010). Our results for $P$. sanguineus show that the highest nitrogen concentration increased laccase production in the sugarcane molasses cultivation medium, as observed by Eugenio et al. (2009) who reported that $P$. sanguineus produced more laccase in the presence of a higher concentration of asparagine $(5 \mathrm{~g} / \mathrm{L})$ in a medium containing sucrose as carbon source. Eggert et al. (1996) and Pointing and Vrijmoed (2000) verified reductions in the laccase activities of Pycnoporus cinnabarinus and $P$. sanguineus, respectively, in the presence of higher nitrogen concentrations; however, the authors used different nitrogen sources: ammonium sulfate (0.6 $\mathrm{g} / \mathrm{L}$ nitrogen) and ammonium tartrate $(0.03 \mathrm{~g} / \mathrm{L}$ nitrogen $)$, respectively. According to Piscitelli et al. (2011), non-protein nitrogen sources reduce laccase production, whereas protein sources increase enzyme production. In our study, the maximum laccase production of $57,067 \mathrm{U} / \mathrm{L}$ by $P$. sanguineus (using urea) was approximately 52 times greater than that by $P$. cinnabarinus using ammonium sulfate (Eggert et al., 1996), 127 times greater than that by $P$. sanguineus using ammonium tartrate (Pointing and Vrijmoed, 2000), and four times greater than that by Lentinus crinitus using urea (Valle et al., 2014b). Therefore, P. sanguineus is an important genetic resource, although other cultivation conditions besides genetic breeding should be studied to improve laccase production.

Copper increases gene transcription of laccase in several fungi. The inductive potential of this metal seems to be related to the copper concentration in the culture medium and the fungus species/strain. In our study, the copper concentration $(0-300 \mu \mathrm{M})$ did not affect $(\mathrm{P} \leq$ 0.05 ) laccase activity of $P$. sanguineus. Fonseca et al. (2010) reported an increase in laccase production by $P$. sanguineus in the presence of $500 \mu \mathrm{M}$ copper. Park et al. (2015) verified that the addition of up to $200 \mu \mathrm{M}$ copper affected laccase production in five of seven strains of Pycnoporus coccineus. These authors also verified that even though all strains had at least one laccase gene $(l c c l)$ two strains did not respond to copper stimulation, maintaining constitutive enzymatic production without an increase in the transcription rate. This suggests that the inducing role of copper in the laccase activity of $P$. sanguineus is directly related to the ability of different strains to adapt to environmental conditions (Park et al., 2015), and an evaluation of potential inducers is necessary for each specific situation and strain.

Agitation during cultivation positively affected $(\mathrm{P} \leq 0.05)$ laccase production, providing a significant gain in enzymatic activity and productivity by $P$. sanguineus. Agitation is a fundamental factor for fungal laccase production in submerged cultivation for several fungus species, providing better homogenization of nutrients to the cultivation medium and guaranteeing better oxygenation (Dekker and Barbosa, 2001).

Genetics and Molecular Research 15 (4): gmr15048972 
The enzymatic extract of $P$. sanguineus obtained at the activity peak $(\sim 50,000 \mathrm{U} / \mathrm{L})$ caused partial decolorization of the anthraquinone and azo dyes within $24 \mathrm{~h}$. RBBR, an important and recalcitrant pollutant, is considered resistant to degradation. However, in our study the enzymatic extract produced $80 \%$ decolorization of this dye (Figure 4), which was the highest level (24 h; pH 5). Similar results were reported by Iracheta-Cárdenas et al. (2016) when the enzymatic extract of $P$. sanguineus caused RBBR decolorization of $90 \%$ (4 h; pH 5), and by Zimbardi et al. (2016) who used a crude enzymatic extract of $P$. sanguineus RP15 to decolorize RBBR by 70 or $80 \%$ ( $2 \mathrm{~h} ; 25$ or $40^{\circ} \mathrm{C}$, respectively).

The efficiency of color removal of dyes catalyzed by laccase depends on the structure of the particular dye (Ali, 2010). Azo dyes can be highly toxic and require enzymes that are more specific to the $\mathrm{N}=\mathrm{N}$ moiety. Aromatic compounds such as the anthraquinone dye RBBR have more affinity for oxidase enzymes such as laccases, and can therefore be decolorized efficiently. Munari et al. (2008) also reported more efficient degradation of anthraquinone dyes than azo dyes by an enzymatic extract of Pleurotus sajor-caju. They also reported that whereas the anthraquinone Acid Blue 80 was totally decolorized ( $1 \mathrm{~h}$; pH 5), the azo dye Reactive Red 198 was decolorized by only $28.5 \%$ (10 h; pH 5).

In conclusion, we verified that urea efficiently stimulates laccase production in cultivation with sugarcane molasses, providing a low-cost alternative for enzymatic production. Copper did not affect $P$. sanguineus laccase activity under the conditions tested. However, the addition of a higher concentration of nitrogen (urea) with agitation of the culture medium increased the production of laccase, with production reaching a maximum of 50,000 $\mathrm{U} / \mathrm{L}$ within 9 days of cultivation; the resulting enzyme was able to degrade dyes, especially anthraquinones. P. sanguineus U13-4 has great potential for laccase production and the treatment of textile dye effluents. Our study suggests that agro-industry by-products other than laccase inducers should be tested to optimize $P$. sanguineus U13-4 laccase productivity and decolorization capability. However, greater effort should be made to optimize decolorization, identify the products of dye biodegradation, and determine their toxicity: aspects that were not the scope of this study. Although the present study has yielded some preliminary results, more investigation is required to justify the use of $P$. sanguineus laccase in biotechnological processes.

\section{Conflicts of interest}

The authors declare no conflict of interest.

\section{ACKNOWLEDGMENTS}

The authors thank Universidade Paranaense, the Postgraduate Program for Biotechnology Applied to Agriculture from Universidade Paranaense, Coordenação de Aperfeiçoamento de Pessoal de Nível Superior (CAPES), and Conselho Nacional de Desenvolvimento Científico e Tecnológico (CNPq) for financial support and fellowship.

\section{REFERENCES}

Ali H (2010). Biodegradation of synthetic dyes - a review. Water Air Soil Pollut. 213: 251-273. http://dx.doi.org/10.1007/ s11270-010-0382-4

Genetics and Molecular Research 15 (4): gmr15048972 
Dye decolorization using Pycnoporus sanguineus laccase

Annuar MSM, Adnan S, Vikineswary S and Chisti Y (2009). Kinetics and energetics of azo dye decolorization by Pycnoporus sanguineus. Water Air Soil Pollut. 202: 179-188. http://dx.doi.org/10.1007/s11270-008-9968-5

CONAB - Companhia Nacional de Abastecimento (2015). Séries históricas relativas às safras 2005/06 a 2014/15 de área plantada, produtividade e produção. Cana-de-açúcar. Available at http://www.conab.gov.br/conteudos. php? $\mathrm{a}=1252$ \&ordem=produto\&Pagina_objcmsconteudos $=2$.

Dekker RF and Barbosa AM (2001). The effects of aeration and veratryl alcohol on the production of two laccases by the ascomycete Botryosphaeria sp. Enzyme Microb. Technol. 28: 81-88. http://dx.doi.org/10.1016/S0141$\underline{0229(00) 00274-X}$

Eggert C, Temp U and Eriksson KE (1996). The ligninolytic system of the white rot fungus Pycnoporus cinnabarinus: purification and characterization of the laccase. Appl. Environ. Microbiol. 62: 1151-1158.

Eugenio ME, Carbajo JM, Martín JA, González AE, et al. (2009). Laccase production by Pycnoporus sanguineus under different culture conditions. J. Basic Microbiol. 49: 433-440. http://dx.doi.org/10.1002/jobm.200800347

Fonseca MI, Shimizu E, Zapata PD and Villalba LL (2010). Copper inducing effect on laccase production of white rot fungi native from Misiones (Argentina). Enzyme Microb. Technol. 46: 534-539. http://dx.doi.org/10.1016/j. enzmictec.2009.12.017

Giardina P, Faraco V, Pezzella C, Piscitelli A, et al. (2010). Laccases: a never-ending story. Cell. Mol. Life Sci. 67: 369385. http://dx.doi.org/10.1007/s00018-009-0169-1

Hernández CA, Perroni Y, Pérez JA, Rivera BG, et al. (2016). Light-induced inhibition of laccase in Pycnoporus sanguineus. Folia Microbiol. (Praha) 61: 137-142. http://dx.doi.org/10.1007/s12223-015-0418-7

Iracheta-Cárdenas MM, Rocha-Peña MA, Galán-Wong LJ, Arévalo-Niño K, et al. (2016). A Pycnoporus sanguineus laccase for denim bleaching and its comparison with an enzymatic commercial formulation. J. Environ. Manage. 177: 93-100. http://dx.doi.org/10.1016/j.jenvman.2016.04.008

Joo JD, Shin WS, Choi J-H, Choi SJ, et al. (2007). Decolorization of reactive dyes using inorganic coagulants and synthetic polymer. Dyes Pigments 73: 59-64. http://dx.doi.org/10.1016/j.dyepig.2005.10.011

Moreira-Neto SL, Mussatto SI, Machado KM and Milagres AM (2013). Decolorization of salt-alkaline effluent with industrial reactive dyes by laccase-producing Basidiomycetes strains. Lett. Appl. Microbiol. 56: 283-290. http:// dx.doi.org/10.1111/lam.12049

Munari FM, Gaio TA, Calloni R and Dillon AJP (2008). Decolorization of textile dyes by enzymatic extract and submerged cultures of Pleurotus sajor-caju. World J. Microbiol. Biotechnol. 24: 1383-1392. http://dx.doi.org/10.1007/s11274$\underline{007-9621-2}$

Park J-W, Kang H-W, Ha B-S, Kim SI, et al. (2015). Strain-dependent response to $\mathrm{Cu}(2+)$ in the expression of laccase in Pycnoporus coccineus. Arch. Microbiol. 197: 589-596. http://dx.doi.org/10.1007/s00203-015-1090-7

Piscitelli A, Giardina P, Lettera V, Pezzella C, et al. (2011). Induction and transcriptional regulation of laccases in fungi. Curr. Genomics 12: 104-112. http://dx.doi.org/10.2174/138920211795564331

Pointing SB and Vrijmoed LLP (2000). Decolorization of azo and triphenylmethane dyes by Pycnoporus sanguineus producing laccase as the sole phenoloxidase. World J. Microbiol. Biotechnol. 16: 317-318. http://dx.doi. org/10.1023/A:1008959600680

Rodriguez-Couto S (2013). Treatment of textile wastewater by white-rot fungi: still a far away reality? TLIST 2: 113-119.

Valle JS, Vandenberghe LPS, Santana TT, Linde GA, et al. (2014a). Optimization of Agaricus blazei laccase production by submerged cultivation with sugarcane molasses. Afr. J. Microbiol. Res. 8: 939-946. http://dx.doi.org/10.5897/ AJMR2013.6508

Valle JS, Vandenberghe LP, Santana TT, Almeida PH, et al. (2014b). Optimum conditions for inducing laccase production in Lentinus crinitus. Genet. Mol. Res. 13: 8544-8551. http://dx.doi.org/10.4238/2014.October.20.31

Valle JS, Vandenberghe LP, Oliveira AC, Tavares MF, et al. (2015). Effect of different compounds on the induction of laccase production by Agaricus blazei. Genet. Mol. Res. 14: 15882-15891. http://dx.doi.org/10.4238/2015. December.1.40

Zimbardi AL, Camargo PF, Carli S, Aquino Neto S, et al. (2016). A high redox potential laccase from Pycnoporus sanguineus RP15: potential application for dye decolorization. Int. J. Mol. Sci. 17: E672 http://dx.doi.org/10.3390/ ijms 17050672 .

Genetics and Molecular Research 15 (4): gmr15048972 